\title{
New diarylmethanofullerene derivatives and their properties for organic thin-film solar cells
}

\author{
Daisuke Sukeguchi, Surya Prakash Singh, Mamidi Ramesh Reddy, \\ Hideyuki Yoshiyama, Rakesh A. Afre, Yasuhiko Hayashi, Hiroki Inukai, \\ Tetsuo Soga, Shuichi Nakamura, Norio Shibata* and Takeshi Toru
}

Open Access

\author{
Full Research Paper \\ Address: \\ Department of Frontier Materials, Graduate School of Engineering, \\ Nagoya Institute of Technology, Gokiso, Showa-ku, Nagoya 466 \\ 8555, Japan \\ Email: \\ Norio Shibata* - shibata.norio@nitech.ac.jp \\ * Corresponding author \\ Keywords: \\ bulk heterojunction solar cells; fullerene derivatives; high open-circuit \\ voltage
}

\author{
Beilstein Journal of Organic Chemistry 2009, 5, No. 7 \\ doi:10.3762/bjoc.5.7 \\ Received: 17 December 2008 \\ Accepted: 09 February 2009 \\ Published: 24 February 2009 \\ Associate Editor: P. Skabara \\ (C) 2009 Sukeguchi et al; licensee Beilstein-Institut. \\ License and terms: see end of document.
}

\begin{abstract}
A number of diarylmethanofullerene derivatives were synthesized. The cyclopropane ring of the derivatives has two aryl groups substituted with electron-withdrawing and -donating groups, the latter with long alkyl chains to improve solubility in organic solvents, an important property in processing cells. First reduction potentials of most derivatives were less negative than that of [6,6]-phenyl-C61-butyric acid methyl ester (PCBM), which is possibly ascribed to their electron-withdrawing nature. Organic thinfilm photovoltaic cells fabricated with poly(3-hexylthiophene) (P3HT) as the electron-donor and diarylmethanofullerene derivatives as the electron-acceptor material were examined. The (methoxycarbonyl)phenyl[bis(octyloxy)phenyl]methano\} fullerene showed power conversion efficiency as high as PCBM, but had higher solubility in a variety of organic solvents than PCBM. The $V_{\text {oc }}$ value was higher than that of PCBM, which is derived from the electron-donating (octyloxy)phenyl group, possibly raising the LUMO level. Photovoltaic effects of the devices fabricated with the derivatives having some electron-withdrawing groups were also examined.
\end{abstract}

\section{Introduction}

Bulk heterojunction photovoltaic cells consisting of thin-film composites of conjugated polymers (donors) and fullerene derivatives (acceptors) are promising candidates for inexpensive, renewable solar energy conversion [1-6]. These organic thin films could also be used as flexible solar cells.

Significant efforts have been made to optimize the powerconversion efficiency (PCE) of solar cells based on poly(3hexylthiophene) (P3HT) as a donor and [6,6]-phenyl-C61butyric acid methyl ester (PCBM) as an acceptor [7-10]. Using a combination of these donor and acceptor molecules together 
with the optimized solvent processing, composition, and effect of device annealing, PCE has reached up to 5\% [11-17]. In addition to PCBM widely studied as the bulk heterojunction (BHJ) acceptor, several methanofullerene derivatives have so far been studied for the development of efficient acceptors such as spiroannulated methanofullerenes [18], diarylmethanofullerenes [19,20], alkoxy-substituted PCBM derivatives [21], and bisPCBM [22]. These derivatives have been shown to have excellent properties as acceptors, but it is still important to study the structure-efficiency relationship of the fullerene structure in order to develop highly efficient OPVs. The design of highly soluble derivatives of PCBM has also attracted much attention because 3D architectures such as vesicles and fibers are highly dependent on the solvent used [23,24]. Recently, we briefly communicated a soluble bulk-heterojunction organic photovoltaic P3HT device using a newly synthesized methanofullerene derivative 1a [25]. In this paper, we give a full account of our studies on new bulk-heterojunction (BHJ) devices composed of P3HT and a variety of newly synthesized diarylmethanofullerene derivative $\mathbf{1 a}-\mathbf{k}, \mathbf{2}$ blends.

\section{Results and Discussion}

We prepared new diarylmethanofullerene derivatives which were studied as electron-accepting materials in the bulk-heterojunction device of organic thin-film photovoltaic cells (Figure 1). The new diarylmethanofullerenes have two aromatic rings on the cyclopropane, having electron-withdrawing and electrondonating groups. The electron-withdrawing groups were expected to increase the electron-accepting ability of fullerene, while the electron-donating groups would decrease the LUMO energy level which leads to an increase of the open-circuit voltage $\left(V_{\text {oc }}\right)$ values of the solar cell. These diarylmethanofullerenes have long alkyl chain(s) to increase the solubility and hopefully to cause the interaction with the donor P3HT polymer, being related to the morphology of the heterojunction thin film.

\section{Synthesis of diarylmethanofullerene derivatives}

Diarylmethanofullerene derivatives were synthesized according to the method cited in the literature [26]. Synthetic routes are shown in Scheme 1.

Generally, the Friedel-Crafts acylation of benzene derivatives 10-14 with acid chlorides 3-9 in the presence of anhydrous $\mathrm{AlCl}_{3}$ gave the carbonyl compounds $\mathbf{1 5 a}-\mathbf{k}$ which were treated with $p$-toluenesulfonylhydrazine to afford the hydrazones $\mathbf{1 6 a}-\mathbf{k}$. Treatment of $\mathbf{1 6} \mathbf{a}-\mathbf{k}$ with sodium methoxide or LiHMDS in $o$-dichlorobenzene (ODCB) gave a mixture of isomeric diarylmethanofullerenes. After purification, thermal treatment under reflux in toluene gave diarylmethanofullerenes $\mathbf{1 a}-\mathbf{k}$ in good yields. The $\mathrm{C}_{70}$ derivative $\mathbf{2}$, a mixture of isomers, was prepared from 16a by a procedure similar to those of $\mathrm{C}_{60}$ derivatives 1a-k using $\mathrm{C}_{70}$ instead of $\mathrm{C}_{60}$. As expected, all the compounds were soluble in all organic solvents tested such as AcOEt, THF, acetone, dichloromethane, toluene and xylenes,

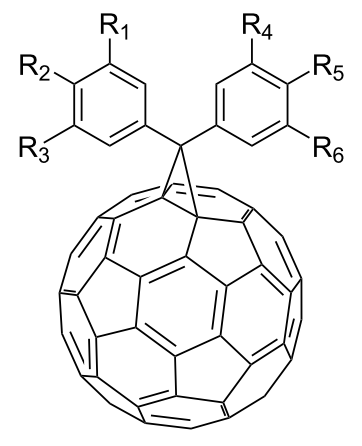

1a-k

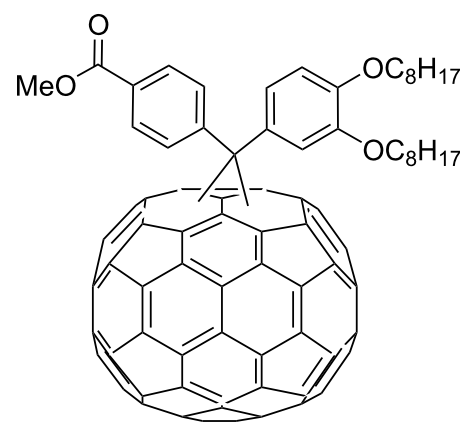

2

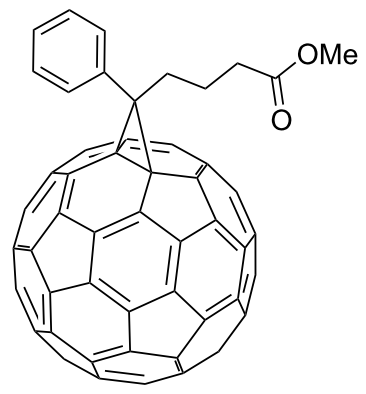

PCBM

1a $\mathrm{R}_{1}=\mathrm{H}, \mathrm{R}_{2}=\mathrm{CO}_{2} \mathrm{Me}, \mathrm{R}_{3}=\mathrm{H}, \mathrm{R}_{4}=\mathrm{H}, \mathrm{R}_{5}=\mathrm{R}_{6}=\mathrm{OC}_{8} \mathrm{H}_{17}$

1b $\mathrm{R}_{1}=\mathrm{H}, \mathrm{R}_{2}=\mathrm{CO}_{2} \mathrm{Me}, \mathrm{R}_{3}=\mathrm{H}, \mathrm{R}_{4}=\mathrm{R}_{5}=\mathrm{R}_{6}=\mathrm{OC}_{8} \mathrm{H}_{17}$

1c $\mathrm{R}_{1}=\mathrm{H}, \mathrm{R}_{2}=\mathrm{CO}_{2} \mathrm{Me}, \mathrm{R}_{3}=\mathrm{H}, \mathrm{R}_{4}=\mathrm{H}, \mathrm{R}_{5}=\mathrm{OC}_{8} \mathrm{H}_{17}, \mathrm{R}_{6}=\mathrm{H}$

1d $R_{1}=H, R_{2}=C_{2} M e, R_{3}=H, R_{4}=H, R_{5}=R_{6}=O M e$

1e $\mathrm{R}_{1}=\mathrm{H}, \mathrm{R}_{2}=\mathrm{CO}_{2} \mathrm{Me}, \mathrm{R}_{3}=\mathrm{H}, \mathrm{R}_{4}=\mathrm{R}_{5}=\mathrm{R}_{6}=\mathrm{H}$

If $\mathrm{R}_{1}=\mathrm{CO}_{2} \mathrm{Me}, \mathrm{R}_{2}=\mathrm{H}, \mathrm{R}_{3}=\mathrm{CO}_{2} \mathrm{Me}, \mathrm{R}_{4}=\mathrm{H}, \mathrm{R}_{5}=\mathrm{R}_{6}=\mathrm{OC}_{8} \mathrm{H}_{17}$

$1 \mathrm{~g} \mathrm{R}_{1}=\mathrm{H}, \mathrm{R}_{2}=\mathrm{CN}, \mathrm{R}_{3}=\mathrm{H}, \mathrm{R}_{4}=\mathrm{H}, \mathrm{R}_{5}=\mathrm{R}_{6}=\mathrm{OC}_{8} \mathrm{H}_{17}$

1h $\mathrm{R}_{1}=\mathrm{H}, \mathrm{R}_{2}=\mathrm{NO}_{2}, \mathrm{R}_{3}=\mathrm{H}, \mathrm{R}_{4}=\mathrm{H}, \mathrm{R}_{5}=\mathrm{R}_{6}=\mathrm{OC}_{8} \mathrm{H}_{17}$

1i $\mathrm{R}_{1}=\mathrm{R}_{2}=\mathrm{H}, \mathrm{R}_{3}=\mathrm{NO}_{2}, \mathrm{R}_{4}=\mathrm{H}, \mathrm{R}_{5}=\mathrm{R}_{6}=\mathrm{OC}_{8} \mathrm{H}_{17}$

1j $R_{1}=\mathrm{H}, \mathrm{R}_{2}=\mathrm{SO}_{2} \mathrm{Me}, \mathrm{R}_{3}=\mathrm{H}, \mathrm{R}_{4}=\mathrm{H}, \mathrm{R}_{5}=\mathrm{R}_{6}=\mathrm{OC}_{8} \mathrm{H}_{17}$

$1 \mathrm{k} \mathrm{R}_{1}=\mathrm{H}, \mathrm{R}_{2}=\mathrm{SO}_{2} \mathrm{CF}_{3}, \mathrm{R}_{3}=\mathrm{H}, \mathrm{R}_{4}=\mathrm{H}, \mathrm{R}_{5}=\mathrm{R}_{6}=\mathrm{OC}_{8} \mathrm{H}_{17}$ 
<smiles>[R]c1cc(C(C)=O)cc([R])c1[R]</smiles>

3-9<smiles>[R]c1cccc([R])c1[R5]</smiles><smiles>[R]c1cc(C(=O)c2cc([R])c([R])c([R])c2)cc([R])c1[R]</smiles>
$p$-toluenesulfonylhydrazine

15a-k<smiles>[R9]C([R])=C</smiles>
reflux, $3 \mathrm{~h}$

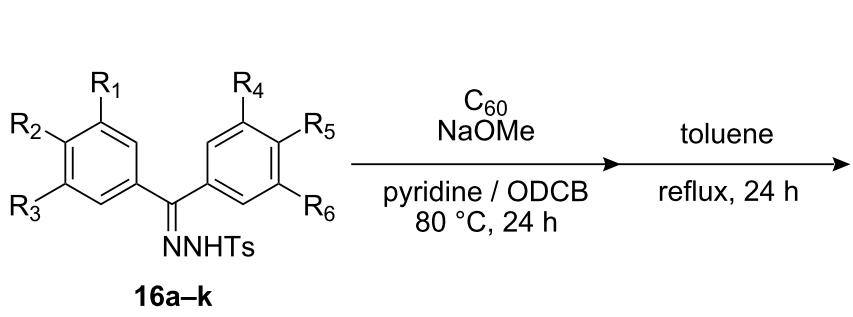<smiles>[R2]c1cc(C2(c3cc([R])c([R])c([R])c3)C(C)C2(C)C)cc([R6])c1[R5]</smiles>
h

3: $\mathrm{R}_{1}=\mathrm{H}, \mathrm{R}_{2}=\mathrm{CO}_{2} \mathrm{Me}, \mathrm{R}_{3}=\mathrm{H}$

10: $\mathrm{R}_{4}=\mathrm{H}, \mathrm{R}_{5}=\mathrm{R}_{6}=\mathrm{OC}_{8} \mathrm{H}_{17}$

11: $\mathrm{R}_{4}=\mathrm{R}_{5}=\mathrm{R}_{6}=\mathrm{OC}_{8} \mathrm{H}_{17}$

4: $\mathrm{R}_{1}=\mathrm{CO}_{2} \mathrm{Me}, \mathrm{R}_{2}=\mathrm{H}, \mathrm{R}_{3}=\mathrm{CO}_{2} \mathrm{Me}$

12: $\mathrm{R}_{4}=\mathrm{H}, \mathrm{R}_{5}=\mathrm{OC}_{8} \mathrm{H}_{17}, \mathrm{R}_{6}=\mathrm{H}$

6: $\mathrm{R}_{1}=\mathrm{H}, \mathrm{R}_{2}=\mathrm{NO}_{2}, \mathrm{R}_{3}=\mathrm{H}$

13: $\mathrm{R}_{4}=\mathrm{H}, \mathrm{R}_{5}=\mathrm{R}_{6}=\mathrm{OMe}$

7: $\mathrm{R}_{1}=\mathrm{R}_{2}=\mathrm{H}, \mathrm{R}_{3}=\mathrm{NO}_{2}$

8: $\mathrm{R}_{1}=\mathrm{H}, \mathrm{R}_{2}=\mathrm{SO}_{2} \mathrm{Me}, \mathrm{R}_{3}=\mathrm{H}$

14: $R_{4}=R_{5}=R_{6}=H$

9: $\mathrm{R}_{1}=\mathrm{H}, \mathrm{R}_{2}=\mathrm{SO}_{2} \mathrm{CF}_{3}, \mathrm{R}_{3}=\mathrm{H}$

15,16,1= a: $\mathrm{R}_{1}=\mathrm{H}, \mathrm{R}_{2}=\mathrm{CO}_{2} \mathrm{Me}, \mathrm{R}_{3}=\mathrm{H}, \mathrm{R}_{4}=\mathrm{H}, \mathrm{R}_{5}=\mathrm{R}_{6}=\mathrm{OC}_{8} \mathrm{H}_{17}$

b: $\mathrm{R}_{1}=\mathrm{H}, \mathrm{R}_{2}=\mathrm{CO}_{2} \mathrm{Me}, \mathrm{R}_{3}=\mathrm{H}, \mathrm{R}_{4}=\mathrm{R}_{5}=\mathrm{R}_{6}=\mathrm{OC}_{8} \mathrm{H}_{17}$

c: $\mathrm{R}_{1}=\mathrm{H}, \mathrm{R}_{2}=\mathrm{CO}_{2} \mathrm{Me}, \mathrm{R}_{3}=\mathrm{H}, \mathrm{R}_{4}=\mathrm{H}, \mathrm{R}_{5}=\mathrm{OC}_{8} \mathrm{H}_{17}, \mathrm{R}_{6}=\mathrm{H}$

d: $\mathrm{R}_{1}=\mathrm{H}, \mathrm{R}_{2}=\mathrm{CO}_{2} \mathrm{Me}, \mathrm{R}_{3}=\mathrm{H}, \mathrm{R}_{4}=\mathrm{H}, \mathrm{R}_{5}=\mathrm{R}_{6}=\mathrm{OMe}$

e: $\mathrm{R}_{1}=\mathrm{H}, \mathrm{R}_{2}=\mathrm{CO}_{2} \mathrm{Me}, \mathrm{R}_{3}=\mathrm{H}, \mathrm{R}_{4}=\mathrm{R}_{5}=\mathrm{R}_{6}=\mathrm{H}$

f: $\mathrm{R}_{1}=\mathrm{CO}_{2} \mathrm{Me}, \mathrm{R}_{2}=\mathrm{H}, \mathrm{R}_{3}=\mathrm{CO}_{2} \mathrm{Me}, \mathrm{R}_{4}=\mathrm{H}, \mathrm{R}_{5}=\mathrm{R}_{6}=\mathrm{OC}_{8} \mathrm{H}_{17}$

g: $\mathrm{R}_{1}=\mathrm{H}, \mathrm{R}_{2}=\mathrm{CN}, \mathrm{R}_{3}=\mathrm{H}, \mathrm{R}_{4}=\mathrm{H}, \mathrm{R}_{5}=\mathrm{R}_{6}=\mathrm{OC}_{8} \mathrm{H}_{17}$

h: $\mathrm{R}_{1}=\mathrm{H}, \mathrm{R}_{2}=\mathrm{NO}_{2}, \mathrm{R}_{3}=\mathrm{H}, \mathrm{R}_{4}=\mathrm{H}, \mathrm{R}_{5}=\mathrm{R}_{6}=\mathrm{OC}_{8} \mathrm{H}_{17}$

i: $\mathrm{R}_{1}=\mathrm{R}_{2}=\mathrm{H}, \mathrm{R}_{3}=\mathrm{NO}_{2}, \mathrm{R}_{4}=\mathrm{H}, \mathrm{R}_{5}=\mathrm{R}_{6}=\mathrm{OC}_{8} \mathrm{H}_{17}$

j: $\mathrm{R}_{1}=\mathrm{H}, \mathrm{R}_{2}=\mathrm{SO}_{2} \mathrm{Me}, \mathrm{R}_{3}=\mathrm{H}, \mathrm{R}_{4}=\mathrm{H}, \mathrm{R}_{5}=\mathrm{R}_{6}=\mathrm{OC}_{8} \mathrm{H}_{17}$

k: $\mathrm{R}_{1}=\mathrm{H}, \mathrm{R}_{2}=\mathrm{SO}_{2} \mathrm{CF}_{3}, \mathrm{R}_{3}=\mathrm{H}, \mathrm{R}_{4}=\mathrm{H}, \mathrm{R}_{5}=\mathrm{R}_{6}=\mathrm{OC}_{8} \mathrm{H}_{17}$

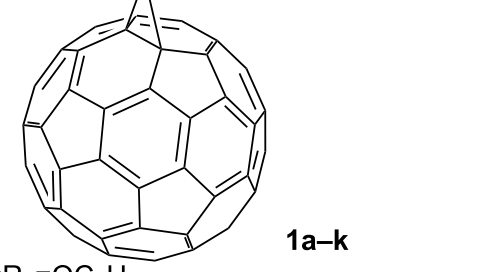

\section{1a-k}

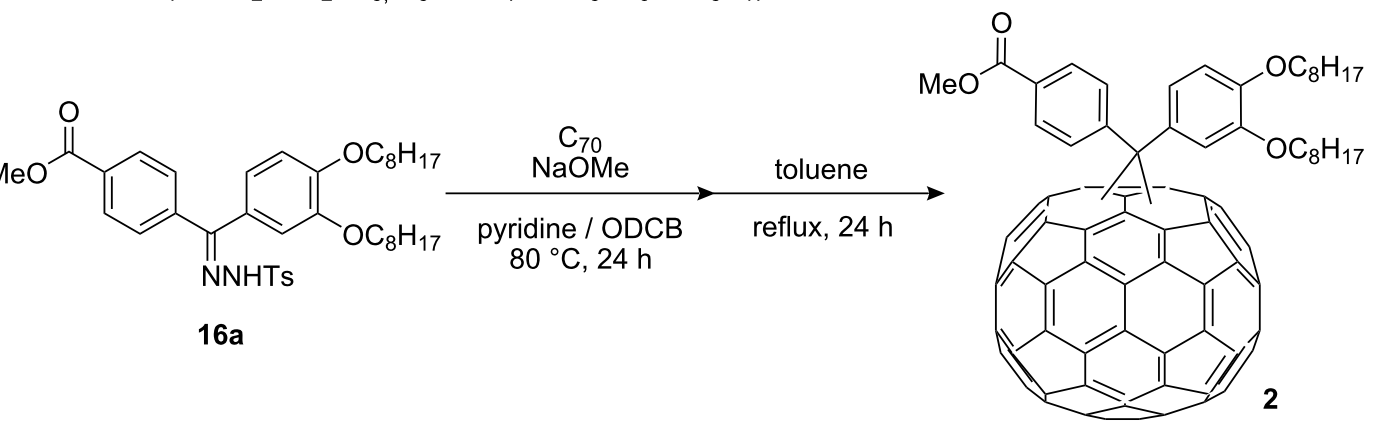

Scheme 1: Synthesis of diarylmethanofullerene derivatives.

while conventional PCBM has high solubility in toluene and xylenes, but limited solubility in AcOEt, THF, and acetone.

\section{Electrochemical Studies}

Electrochemical studies were performed by differential pulse voltammetry (DPV) using a platinum electrode and tetrabutylammonium hexafluorophosphate as the supporting electrolyte in THF. Reduction potentials are listed in Table 1. The obtained cyclic voltammetry data were reversible. The first reduction potentials depend on the electron-donating nature of the substituents, in which tris(octyloxy)phenyl compound $\mathbf{1 b}$ showed a more negative value than mono- and bis(octyloxy)phenylmethanofullerenes 1c and 1a. When compared with PCBM, most derivatives except 1e showed first reduction potentials with less negative values. It is reasonable that less negative values are derived from the electron-withdrawing nature of the (methoxycarbonyl)phenyl, cyanophenyl, nitrophenyl, (methylsulfonyl)phenyl, and (trifluoromethylsulfonyl)phenyl groups attached to the cyclopropane ring, enough to compensate the opposite effect of the electron-donating mono-, bis-, or tris(octyloxy)phenyl group [19]. These first reduction potential data showed that the diarylmethan- 


\begin{tabular}{|c|c|c|c|c|c|c|}
\hline Derivative & $\mathrm{E}^{1}$ red & $E^{2}$ red & $E^{3}$ red & $\mathrm{E}^{4}{ }_{\text {red }}$ & $\mathrm{E}^{5}$ red & $\mathrm{E}_{\text {red }}^{6}$ \\
\hline $1 a$ & -0.900 & -1.205 & -1.420 & -1.770 & -2.270 & \\
\hline $1 b$ & -0.945 & -1.376 & -1.885 & -2.100 & -2.395 & \\
\hline $1 c$ & -0.905 & -1.285 & -1.505 & -1.775 & -2.265 & \\
\hline 1d & -0.835 & -1.210 & -1.715 & -2.155 & & \\
\hline $1 e$ & -1.050 & -1.320 & -1.800 & -2.275 & & \\
\hline $1 f$ & -0.915 & -1.290 & -1.530 & -1.705 & -2.320 & \\
\hline $1 \mathrm{~g}$ & -0.905 & -1.455 & -1.836 & -2.275 & & \\
\hline $1 \mathrm{~h}$ & -0.890 & -1.270 & -1.770 & -2.245 & & \\
\hline $1 i$ & -0.890 & -1.290 & -1.590 & -1.885 & -2.170 & -2.350 \\
\hline $1 \mathrm{j}$ & -0.883 & -1.253 & -1.780 & -2.252 & & \\
\hline $1 \mathrm{k}$ & -0.897 & -1.279 & -1.737 & -1.873 & & \\
\hline 2 & -0.915 & -1.385 & -1.565 & -1.725 & -1.865 & -2.125 \\
\hline РСBM & -1.049 & -1.290 & -1.535 & -1.785 & -2.285 & \\
\hline
\end{tabular}

${ }^{a} \mathrm{~A} 3 \mathrm{~mm}$ platinum plate was used as working electrode and a platinum wire as counter electrode. Ag/AgNO $3(0.01 \mathrm{M}$ in MeCN/0.1 M TBAPF) was used as reference electrode separated by $V_{y c o r}{ }^{\circledR}$ glass, and all potentials are given in relation to this electrode. The measurements were performed using a concentration of approximately $0.5 \mathrm{mM}$ of the compounds.

ofullerene derivatives can be a better electron acceptor than PCBM [27].

\section{Photovoltaic Devices}

A series of solar cells was fabricated with $\mathrm{P} 3 \mathrm{HT}$ as the electrondonor and diarylmethanofullerene derivatives as the electronacceptor material. Sandwich configurations are described as ITO/PEDOT:PSS/P3HT:diarylmethanofullerene derivatives/Al (Figure 2). The ITO/PEDOT:PSS/P3HT:PCBM/Al cell was also fabricated for a comparative study. The conducting polymer, poly(3,4-ethylenedioxythiophene):poly(styrenesulfonate) (PEDOT:PSS), acting as a buffer layer for hole transport and reducing the roughness of the ITO surface, was spin-coated by $2000 \mathrm{rpm}$ on the ITO-glass substrate with a thickness of $\sim 80 \mathrm{~nm}$ from aqueous solution. The layer was then annealed at $120{ }^{\circ} \mathrm{C}$ for $10 \mathrm{~min}$ to remove the residual water. An ODCB solution of $\mathrm{P} 3 \mathrm{HT}$ and the diarylmethanofullerene derivative or

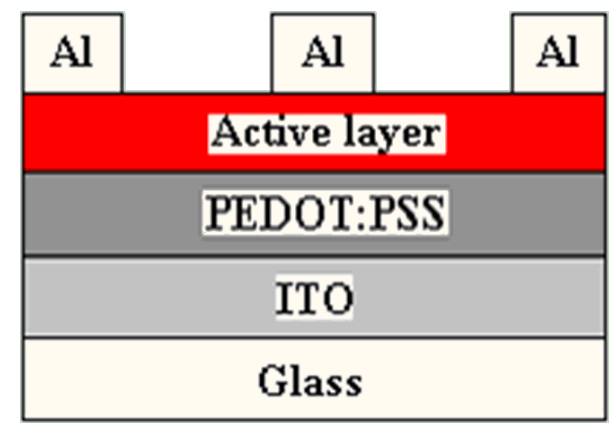

Figure 2: Device layout of the solar cell.
PCBM in a 1:1 weight ratio [28] prepared by stirring for a day was spin-coated and subsequently the device was heated at $130{ }^{\circ} \mathrm{C}$ for $30 \mathrm{~min}$. The $\mathrm{Al}$ cathode layer was deposited with a thickness of $\sim 100 \mathrm{~nm}$ by thermal evaporation in a vacuum chamber under $3 \times 10^{-4} \mathrm{~Pa}$. After thermal evaporation of the $\mathrm{Al}$ cathode layer, the device was annealed at $140{ }^{\circ} \mathrm{C}$ for $10 \mathrm{~min}$ in a glove box. The active area of the device was defined in an area of $3 \mathrm{~mm}^{2}$ with a shadow mask (Figure 2).

Current density-voltage $(J-V)$ characteristics of the device were measured under one-sun illumination using an AM1.5G filter with a white light xenon lamp under a nitrogen atmosphere. A photovoltaic effect of these devices was clearly visible under exposure to light. OPVs fabricated with P3HT:diarylmethanofullerene derivatives having electron-withdrawing groups such as bis(methoxycarbonyl)phenyl, cyanophenyl, 3- and 4-nitrophenyl, (methylsulfonyl)phenyl, and (trifluoromethylsulfonyl)phenyl groups, taking a P3HT:PCBM-blended cell as a reference, were examined. Table 2 shows the current density-voltage $(J-V)$ characteristic parameters of the devices structured from P3HT:diarylmethanofullerene derivatives $\mathbf{1 a - 1 k , 2}$ and P3HT:PCBM blends.

Derivative 1a having methoxycarbonylphenyl and bis(octyloxy)phenyl groups was shown to be a superior acceptor in combination with P3HT and PCE of the P3HT:1a blended cell was as high as that of PCBM. Especially, the $V_{\text {oc }}$ value of the P3HT:1a cell was $0.61 \mathrm{~V}, 0.09 \mathrm{~V}$ higher than that of the P3HT:PCBM cell. This could be generally ascribed to the reduced LUMO level of the methanofullerene by the electrondonating bis(octyloxy)phenyl group, since the band gap 
Table 2: $J-V$ characteristic parameters of bulk-heterojunction solar cells

\begin{tabular}{lllll} 
Derivative & Eff $(\%)^{\mathrm{a}}$ & $F F^{\mathrm{b}}$ & $V_{\mathrm{OC}}{ }^{\mathrm{c}}$ & $J_{\mathrm{SC}}{ }^{\mathrm{d}}$ \\
\hline 1a & 1.93 & 0.59 & 0.61 & 5.41 \\
1b & 1.50 & 0.49 & 0.66 & 4.60 \\
1c & 1.05 & 0.39 & 0.60 & 4.43 \\
1d & 0.022 & 0.18 & 0.49 & 0.25 \\
1e & $-\mathrm{e}$ & - & - & - \\
1f & 1.00 & 0.59 & 0.54 & 3.13 \\
19 & 0.84 & 0.40 & 0.52 & 4.09 \\
1h & 0.051 & 0.21 & 0.35 & 0.69 \\
1i & $-\mathrm{e}$ & - & - & - \\
1j & 1.24 & 0.50 & 0.56 & 4.43 \\
1k & 0.86 & 0.43 & 0.48 & 4.20 \\
$\mathbf{2}$ & 1.60 & 0.55 & 0.60 & 4.90 \\
PCBM & 1.98 & 0.56 & 0.52 & 6.82 \\
\hline
\end{tabular}

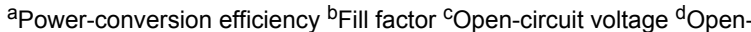
circuit current ${ }^{\mathrm{P}}$ Power conversion was not observed.

between the HOMO level of the P3HT and the LUMO level of the acceptor is related to the $V_{\mathrm{oc}}$ value, the higher band gap corresponding to the higher $V_{\text {oc }}$ value [20,27,29-31]. More negative first reduction potentials of the methoxy-substituted PCBM derivatives in comparison with that of PCBM have been shown to be well correlated to the $V_{\mathrm{oc}}$ values of the solar cells [20]. On the other hand, the first reduction potential of $\mathbf{1 a}$ is less negative than that of PCBM (Table 1). In addition, a higher $V_{\mathrm{oc}}$ value was shown for the P3HT-1a cell. The tris(octyloxy)phenyl- and (octyloxy)phenyl-substituted methan- ofullerenes 1b and 1c with less negative first reduction potential also showed enhanced $V_{\text {oc }}$ values. The electron-donating (octyloxy)phenyl groups seemingly mainly worked on this effect. The first reduction potentials of the derivatives 1d, $\mathbf{1 f}-\mathbf{1 k}$, and $\mathbf{2}$ having electron-withdrawing groups are also less negative than that of PCBM. It should be noted that the derivatives 1a-1c having the methoxycarbonylphenyl group exhibited enhanced $V_{\text {oc }}$ values as compared with lower $V_{\text {oc }}$ values for the cells fabricated with other derivatives $\mathbf{1 d}, \mathbf{1 f}-\mathbf{1 k}$, and 2. The reason is not clear but the lower $V_{\text {oc }}$ values may be a consequence of negative effects such as morphology problems relating to inefficient charge transfer or charge separation. A more detailed study is necessary to elucidate these results. Short-circuit current $\left(J_{\mathrm{sc}}\right)$ and fill factor $(F F)$ values for 1a-1c were lower in comparison with that for PCBM. Dimethoxyphenyl- and (methoxycarbonyl)phenyl-substituted, and phenyl- and (methoxycarbonyl)phenyl-substituted methanofullerenes 1d and 1e did not work as acceptors, probably because of their low solubility in ODCB. The bis(methoxycarbonyl)phenyl- and cyanophenyl-substituted methanofullerenes 1f and $\mathbf{1 g}$ showed good PCE, whereas nitrophenyl-substituted methanofullerenes $\mathbf{1 h}$ and $\mathbf{1 i}$ did not work as acceptors. (Methoxycarbonyl)phenylmethano- $\mathrm{C}_{70}$ derivative $\mathbf{2}$ showed excellent PCE. (Methylsulfonyl)phenyl- and (trifluoromethylsulfonyl)phenyl-substituted methanofullerenes $\mathbf{1 j}$ and $\mathbf{1 k}$ also worked fine.

The current density-voltage $(J-V)$ characteristics of the OPVs structured from P3HT:1a and P3HT:PCBM blends were annealed at 140,130 , and $100^{\circ} \mathrm{C}$ for 30 min after cathode (Al)
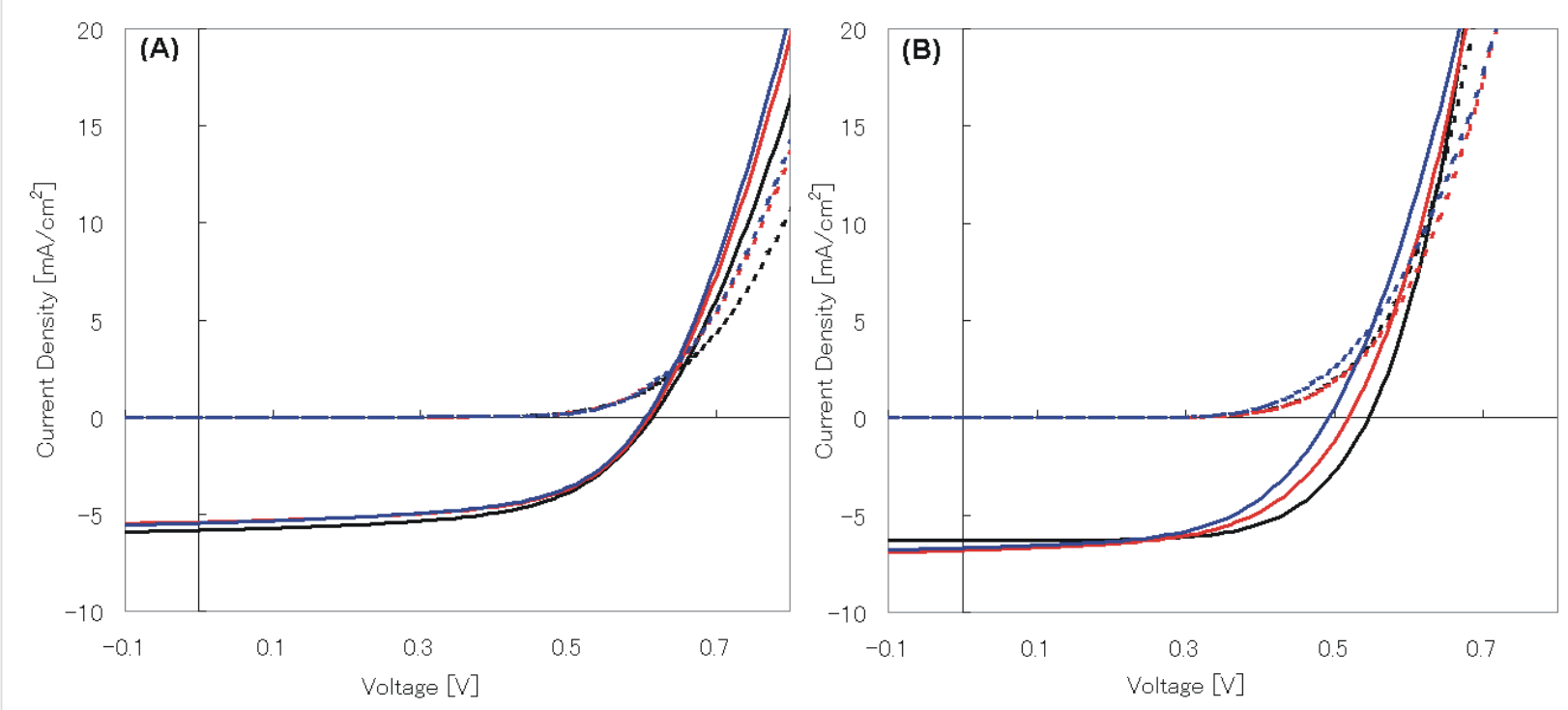

Figure 3: (A) $J-V$ characteristics of the P3HT:1a-blended device annealed at $100-140{ }^{\circ} \mathrm{C}$ (black: $100{ }^{\circ} \mathrm{C}$, red: $130{ }^{\circ} \mathrm{C}$, blue: $140{ }^{\circ} \mathrm{C}$, solid line: current under light, dashed line: current under dark). (B) J-V characteristics of the P3HT:PCBM-blended device annealed at $100-140{ }^{\circ} \mathrm{C}$ (black: $100{ }^{\circ} \mathrm{C}$, red: $130^{\circ} \mathrm{C}$, blue: $140{ }^{\circ} \mathrm{C}$, solid line: with light current, dashed line: with dark current). 

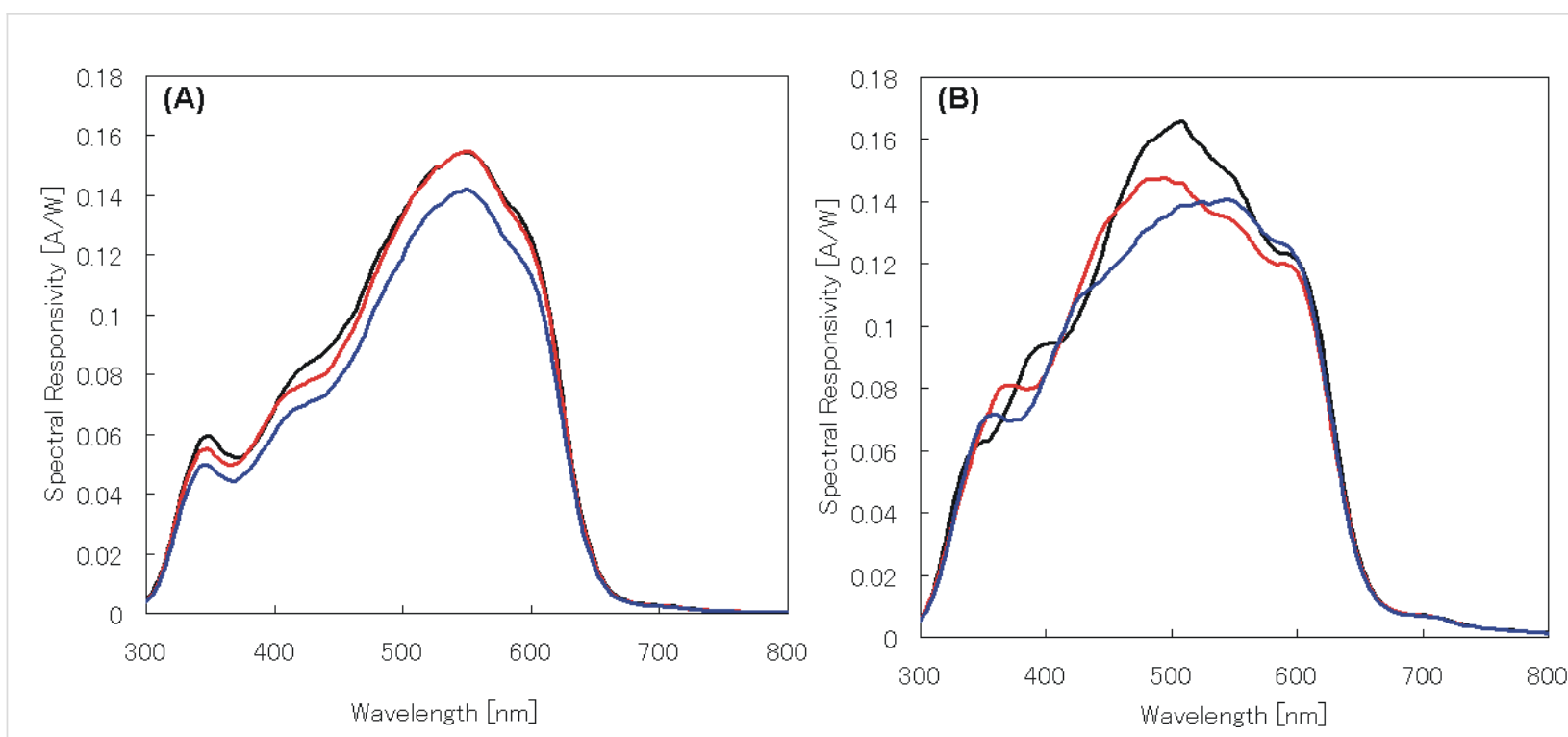

Figure 4: (A) Spectral responsivity of the P3HT:1a-blended film on the ITO glass annealed at $100-140{ }^{\circ} \mathrm{C}\left(100{ }^{\circ} \mathrm{C}\right.$ : black, $130{ }^{\circ} \mathrm{C}$ : red, $140{ }^{\circ} \mathrm{C}$ : blue). (B) Spectral responsivity of the P3HT:PCBM-blended film on the ITO glass annealed at $100-140^{\circ} \mathrm{C}\left(100^{\circ} \mathrm{C}\right.$ : black, $130{ }^{\circ} \mathrm{C}$ : red, $140{ }^{\circ} \mathrm{C}$ : blue).

deposition. The PCE values of the P3HT:1a-blended cell increased slightly as the annealing temperature decreased from 140 to $100{ }^{\circ} \mathrm{C}$; thus, the PCE values of $1.91,1.93$, and $2.06 \%$ were obtained at the annealing temperatures of 140,130, and $100{ }^{\circ} \mathrm{C}$, respectively. Figure 3 shows the $J-V$ characteristics of the P3HT:1a and P3HT:PCBM solar cells. Figure 4 shows the spectral responsibilities for both solar cells. $J_{\text {sc }}, V_{\text {oc }}$ and $F F$ values of the P3HT:1a-blended cell did not significantly alter at these annealing temperatures [Figure 3(A)]. On the other hand, the $J-V$ characteristics of the P3HT:PCBM-blended cell varied significantly depending on the annealing temperatures [Figure 3(B)].

Figure 4(A) shows the spectral responsivities of the P3HT:1abased cell with annealing at 140,130 , and $100{ }^{\circ} \mathrm{C}$. Similar spectral responsivities were obtained irrespective of the annealing

\begin{tabular}{|c|c|c|c|c|c|}
\hline Cell & Temperature $\left({ }^{\circ} \mathrm{C}\right)$ & Eff (\%) & $F F$ & $V_{o c}$ & $J_{\mathrm{sc}}$ \\
\hline \multirow[t]{5}{*}{ Р3HT:1a } & 60 & 1.93 & 0.54 & 0.55 & 6.41 \\
\hline & 80 & 1.88 & 0.56 & 0.57 & 5.80 \\
\hline & 100 & 2.06 & 0.57 & 0.61 & 5.83 \\
\hline & 130 & 1.93 & 0.59 & 0.61 & 5.41 \\
\hline & 140 & 1.91 & 0.58 & 0.61 & 5.47 \\
\hline \multirow[t]{3}{*}{ Р3НT:PCBM } & 100 & 2.19 & 0.64 & 0.55 & 6.31 \\
\hline & 130 & 1.98 & 0.56 & 0.52 & 6.82 \\
\hline & 140 & 1.84 & 0.56 & 0.49 & 6.69 \\
\hline
\end{tabular}

temperatures with slight decrease of that at $140{ }^{\circ} \mathrm{C}$. The P3HT:1a-based cell showed a maximum at around $550 \mathrm{~nm}$, whereas the P3HT:PCBM annealed at 100 and $130{ }^{\circ} \mathrm{C}$ exhibited the maxima at around $505 \mathrm{~nm}$ as shown in Figure 4(B). Since these responsivities are definitely derived from the absorption of P3HT, this notable bathochromic shift in the responsivity maxima of $\mathrm{P} 3 \mathrm{HT}: \mathbf{1 a}$ in comparison with P3HT:PCBM can be ascribed to the change in the alignment of the P3HT polymer chain induced by the long octyloxy chains of 1a. A change of the annealing temperature may also be related to the growth of the domain size of derivative 1a, as observed in the case of PCBM [32-34], which possibly makes the conjugation length of P3HT longer. AFM measurements were performed on P3HT:1a and P3HT:PCBM films with different annealing temperatures. Different results were obtained between P3HT/1a and P3HT/PCBM: substantially similar low roughness values were observed in the AFM image of $\mathrm{P} 3 \mathrm{HT} / \mathbf{1 a}$ annealed at $100,130,140{ }^{\circ} \mathrm{C}$ (r.m.s. $\left.=0.9-1.1 \mathrm{~nm}\right)$. On the other hand, films of $\mathrm{P} 3 \mathrm{HT} / \mathrm{PCBM}$ showed similar roughness at 130 and $140{ }^{\circ} \mathrm{C}$ (r.m.s. $\left.=1.4-1.6 \mathrm{~nm}\right)$, but a coarser surface was observed at $100{ }^{\circ} \mathrm{C}$ (r.m.s. $=2.2-2.6 \mathrm{~nm}$ ). The P3HT/PCBM cell showed the highest efficiency. This is in accord with the data in which higher roughness gives a more efficient device [32-34]. As shown in Table 3, the highest efficiency was obtained for the P3HT:1a cell when annealed at $100{ }^{\circ} \mathrm{C}$ with a small PCE change in between 100 and $140{ }^{\circ} \mathrm{C}$ (Figure 5).

\section{Conclusion}

In conclusion, a variety of new and highly soluble diarylmethanofullerene derivatives $\mathbf{1 a}-\mathbf{k}$ having electron-withdrawing and 

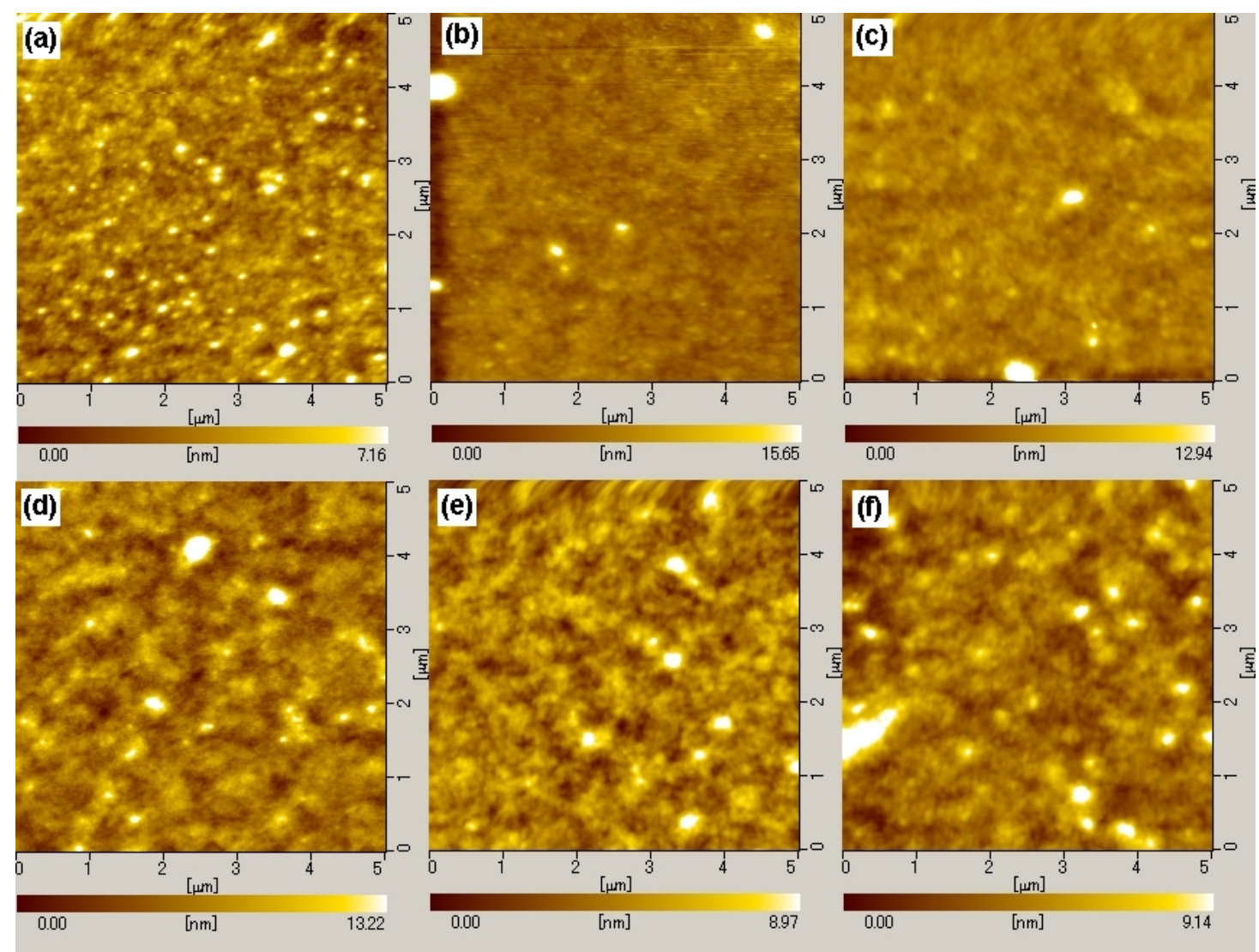

Figure 5: The AFM images of the P3HT:1a- and P3HT:PCBM-blended films annealed at different temperatures. (A) P3HT:1a-blended film annealed at $100{ }^{\circ} \mathrm{C}$ for $30 \mathrm{~min}$, Ra:0.8161 nm, P-V: $15.02 \mathrm{~nm}$ : RMS: 1.110 . (B) P3HT:1a-blended film annealed at $130{ }^{\circ} \mathrm{C}$ for 30 min Ra: $0.6775 \mathrm{~nm}, \mathrm{P}-\mathrm{V}$ : 17.51 nm, RMS: $0.9067 \mathrm{~nm}$. (C) P3HT:1a-blended film annealed at $140^{\circ} \mathrm{C}$ for $30 \mathrm{~min}$, Ra: $0.8884 \mathrm{~nm}, \mathrm{P}-\mathrm{V}: 69.73 \mathrm{~nm}, \mathrm{RMS}: 1.734 \mathrm{~nm}$. (D) P3HT:PCBMblended film annealed at $100{ }^{\circ} \mathrm{C}$ for $30 \mathrm{~min}$, Ra: $1.531 \mathrm{~nm}$, P-V: $35.72 \mathrm{~nm}$, RMS: $2.159 \mathrm{~nm}$. (E) P3HT:PCBM-blended film annealed at $130{ }^{\circ} \mathrm{C}$ for 30 min, Ra: $1.083 \mathrm{~nm}$, P-V: $15.34 \mathrm{~nm}$, RMS: $1.418 \mathrm{~nm}$. (F) P3HT:PCBM-blended film annealed at $140{ }^{\circ} \mathrm{C}$ for $30 \mathrm{~min}$, Ra: $1.135 \mathrm{~nm}, \mathrm{P}-\mathrm{V}: 13.47 \mathrm{~nm}$, RMS: 1.573.

-donating groups were studied as acceptors of the BHJ device. Compared with the P3HT:PCBM blend, the P3HT:diarylmethanofullerene derivatives blend had decreased first reduction potential due to the electron-withdrawing aryl groups attached to the cyclopropane ring, possibly enhancing the acceptability of the fullerene moiety. Higher $V_{\text {oc }}$ values were obtained due mainly to the electron-donating group, while the $J_{\mathrm{sc}}$ values were lowered. In particular, derivative $\mathbf{1}$ a having (methoxycarbonyl)phenyl and bis(octyloxy)phenyl groups was shown to be a superior acceptor in combination with P3HT and the PCE of the P3HT:1a blended cell was as high as that of PCBM. The annealing conditions were shown to be important in further improvement of the PCE values. The highest PCEs of both cells were obtained at a lower annealing temperature $\left(100{ }^{\circ} \mathrm{C}\right)$. Their spectral responsivities and the AFM measurements suggested a change of the P3HT alignment depending on the annealing temperatures. These observations will lead the way to further development of highly efficient acceptors for organic thin-film solar cells.

\section{Experimental}

\section{Representative procedure: Preparation of 1a} Methyl 4-[3,4-bis(octyloxy)benzoyl]benzoate (15a)

To a solution of terephthalic acid monomethyl ester chloride (3, $268 \mathrm{mg}, 1.35 \mathrm{mmol})$ in $\mathrm{CH}_{2} \mathrm{Cl}_{2}(6 \mathrm{~mL})$ was added aluminium trichloride $(199 \mathrm{mg}, 1.49 \mathrm{mmol})$ in portions at $0{ }^{\circ} \mathrm{C}$ and subsequently a solution of 1,2-bis(octyloxy)benzene (10, $500 \mathrm{mg}, 1.49 \mathrm{mmol})$ in $\mathrm{CH}_{2} \mathrm{Cl}_{2}(4 \mathrm{~mL})$. The reaction mixture was stirred for $45 \mathrm{~min}$. The resultant clear solution was stirred for an additional $20 \mathrm{~min}$ at $40{ }^{\circ} \mathrm{C}$, when the color of the reaction mixture turned reddish brown. The reaction mixture was washed with brine. The organic layer was dried over $\mathrm{MgSO}_{4}$ and evaporated under vacuum to leave a solid which was purified by silica gel column chromatography (ethyl acetate/hexane $=10: 90$ as eluent) to give $\mathbf{1 5 a}(624 \mathrm{mg}, 93 \%) .{ }^{1} \mathrm{H}$ NMR $\left(\mathrm{CDCl}_{3}, 200 \mathrm{MHz}\right): \delta 8.14(\mathrm{~d}, J=7.8 \mathrm{~Hz}, 2 \mathrm{H}), 7.79(\mathrm{~d}, J=8.0$ $\mathrm{Hz}, 2 \mathrm{H}), 7.46$ (s, 1H), $7.32(\mathrm{dd}, J=2.0,13.6 \mathrm{~Hz}, 1 \mathrm{H}), 6.88$ (d, $J$ $=8.4 \mathrm{~Hz}, 1 \mathrm{H}), 4.10-4.00(\mathrm{~m}, 4 \mathrm{H}), 3.96(\mathrm{~s}, 3 \mathrm{H}), 1.89-1.80(\mathrm{~m}$, $4 \mathrm{H}), 1.56-1.28(\mathrm{~m}, 20 \mathrm{H}), 0.91(\mathrm{t}, J=6.6 \mathrm{~Hz}, 6 \mathrm{H}) ;{ }^{13} \mathrm{C}\left(\mathrm{CDCl}_{3}\right.$, 
$50.3 \mathrm{MHz}$ ): $\delta$ 194.32, 166.00, 153.33, 148.59, 142.01, 132.33, 129.14, 129.09, 129.03, 125.36, 113.85, 111.13, 69.21, 69.04, 52.42, 31.91, 29.47, 29.44, 29.37, 29.24, 29.14, 26.12, 26.09, 22.81, 14.27; FT-IR (KBr, cm ${ }^{-1}$ ): 2954, 2929, 2856, 1725, 1642; MS (EI) $m / z$ 496; Anal. calcd. for $\mathrm{C}_{31} \mathrm{H}_{44} \mathrm{O}_{5}$ : C, 74.96; $\mathrm{H}$, 8.93. Found: C; 75.03, H; 8.92.

Methyl 4-\{1-(2-tosylhydrazono)-1-[3,4bis(octyloxy)phenyl]methyl\}benzoate (16a)

A solution of 15a (1 g, $2.01 \mathrm{mmol})$ and $p$-toluenesulfonylhydrazine ( $937 \mathrm{mg}, 5.03 \mathrm{mmol})$ in methanol $(15 \mathrm{~mL})$ was heated under reflux for $5 \mathrm{~h}$. The solvent was removed under vacuum to give a solid which was purified by silica gel column chromatography (ethyl acetate/hexane $=25: 75$ as eluent) to give 16a (800 mg, 63\%). ${ }^{1} \mathrm{H}$ NMR $\left(\mathrm{CDCl}_{3}, 200 \mathrm{MHz}\right): \delta 8.17$ (d, $J=8.2$ $\mathrm{Hz}, 2 \mathrm{H}), 7.85(\mathrm{~d}, J=8.2 \mathrm{~Hz}, 2 \mathrm{H}), 7.32-7.17(\mathrm{~m}, 5 \mathrm{H}), 6.65-6.61$ (m, 2H), 3.98-3.90 (m, 4H, s, 3H), 2.43 (s, 3H), 1.85-1.58 (m, $4 \mathrm{H}), 1.57-1.29(\mathrm{~m}, 20 \mathrm{H}), 0.90(\mathrm{t}, J=6.4 \mathrm{~Hz}, 6 \mathrm{H}) ;{ }^{13} \mathrm{C}\left(\mathrm{CDCl}_{3}\right.$, $50.3 \mathrm{MHz}): \delta 165.63,153.10,150.78,148.44,143.79,135.69$, $135.05,131.17,130.37,129.28,129.02,128.36,128.29,127.7$, $125.94,121.51,111.85,111.37,69.05,68.91,52.46,31.89$, $31.85,29.48,29.38,29.31,29.27,29.15,29.16,26.05,22.78$, 22.75, 21.73, 14.23; FT-IR (KBr, $\left.\mathrm{cm}^{-1}\right): 2928,2854,1725$, 1509; MS (EI) $m / z$ 664; Anal. calcd. for $\mathrm{C}_{38} \mathrm{H}_{52} \mathrm{~N}_{2} \mathrm{O}_{6} \mathrm{~S}$ : C; 68.64, H; 7.88, N; 4.21. Found: C; 68.92, H; 8.19, N; 4.21.

\section{Methyl 4-\{[6,6]-1-[3,4-bis(octyloxy)phenyl]C61\}- benzoate (1a)}

To a solution of $16 \mathbf{a}(613 \mathrm{mg}, 0.92 \mathrm{mmol})$ in dry pyridine $(5.0$ $\mathrm{mL}$ ) was added sodium methoxide (50 mg, $0.92 \mathrm{mmol})$. After stirring for $30 \mathrm{~min}$ at room temperature, a solution of $\mathrm{C}_{60}$ (398 $\mathrm{mg}, 0.55 \mathrm{mmol})$ of in dry ODCB $(10 \mathrm{~mL})$ was added. The resulting mixture was stirred at $80{ }^{\circ} \mathrm{C}$ for $24 \mathrm{~h}$. The reaction mixture was washed with diluted $\mathrm{HCl}$ aqueous solution and brine successively. Solvents were removed under vacuum to give the crude product which was purified by column chromatography (silica gel; toluene). First fraction was unreacted $\mathrm{C}_{60}$. Fractions containing brown color were collected and the solvent was evaporated to leave a solid. This compound was dissolved in toluene and refluxed for $24 \mathrm{~h}$ to complete the isomerisation. The isomerisation was confirmed by HPLC (Develosil ODSHG-5, $\mathrm{MeOH} / \mathrm{CHCl}_{3}$ ) and ${ }^{13} \mathrm{C} \mathrm{NMR}$. Further purification by column chromatography as above yielded 1a (112 mg, 17\%). ${ }^{1} \mathrm{H} \mathrm{NMR}\left(\mathrm{CDCl}_{3}, 200 \mathrm{MHz}\right): \delta 8.15$ (br s, 4H), $7.61(\mathrm{~m}, 2 \mathrm{H})$, $6.96(\mathrm{~d}, J=8.0 \mathrm{~Hz}, 2 \mathrm{H}), 4.12-3.98(\mathrm{~m}, 4 \mathrm{H}), 3.92(\mathrm{~s}, 3 \mathrm{H})$, $1.83-1.79(\mathrm{~m}, 4 \mathrm{H}), 1.56-1.28(\mathrm{~m}, 20 \mathrm{H}), 0.87$ (br s, $6 \mathrm{H}) ;{ }^{13} \mathrm{C}$ $\left(\mathrm{CDCl}_{3}, 50.3 \mathrm{MHz}\right) \delta 166.23,149.18,148.30,147.60,147.54$, $144.99,144.82,144.42,144.36,144.33,143.97,143.50,142.62$, $142.57,141.94,141.88,141.80,140.58,138.12,137.67,130.60$, $130.04,129.85,129.51,123.95,117.10,113.05,78.78,69.81$, $68.98,57.46,52.31,32.00,31.96,29.65,29.54,29.44,26.26$,
26.22, 22.86, 14.38; FT-IR (KBr, $\left.\mathrm{cm}^{-1}\right):$ 2923, 2853, 1725, 1608, 1511, 1464, 1430, 1275, 1186, 1136, 1107; MALDI-TOF MS: $m / z$ 1200; Anal. calcd. for $\mathrm{C}_{91} \mathrm{H}_{44} \mathrm{O}_{4}$ : C; 90.98, $\mathrm{H} ; 3.69$. Found: C; 89.41, H; 3.45.

\section{Photovoltaic cells}

After rubbing with cloth to remove the protrusions, the ITOglass (FINE brand, Furuuchi Co. Ltd., $15 \Omega / \mathrm{cm}^{2}$ ) substrate was cleaned successively with acetone, methanol, and a copious amount of water, and dried by a $\mathrm{N}_{2}$ blower. The conducting polymer, poly(3,4-ethylenedioxythiophene):poly(styrenesulfonate) (PEDOT:PSS, Sigma-Aldrich), acting as a buffer layer for hole transport and reducing the roughness of the ITO surface, was spin-coated by $2000 \mathrm{rpm}$ on the ITO-glass substrate with a thickness of $\sim 80 \mathrm{~nm}$ from the aqueous solution. These layers were then annealed at $100{ }^{\circ} \mathrm{C}$ for $10 \mathrm{~min}$ to remove the residual water. P3HT was purchased from Sigma-Aldrich. An ODCB solution $(15 \mathrm{mg} / \mathrm{mL})$ of P3HT and the diarylmethanofullerene derivatives $\mathbf{1 a}-\mathbf{k}, \mathbf{2}$ in a 1:1 weight ratio prepared by stirring for a day was spin-coated by $2000 \mathrm{rpm}$ and the resultant layers were heated at appropriate temperatures. The Al cathode layer was deposited on the film with a thickness of $\sim 100 \mathrm{~nm}$ by thermal evaporation in a vacuum chamber under $3 \times 10^{-4} \mathrm{~Pa}$. The active area of the device was defined in an area of $3 \mathrm{~mm}^{2}$ with a shadow mask. After thermal evaporation of the Al cathode layer, the device was annealed at $140{ }^{\circ} \mathrm{C}$ for $10 \mathrm{~min}$. All the above operations were conducted in a glove box filled with nitrogen. Current density-voltage $(J-V)$ characteristics of the device was measured by a JASCO instrument under one-sun illumination using an AM 1.5G filter with a white light xenon lamp $\left(100 \mathrm{~mW} / \mathrm{cm}^{2}\right)$ under the nitrogen atmosphere. Optical absorption spectra of the device were measured by UV/VIS/ NIR spectrophotometer (V-570 JASCO). The device with P3HT:PCBM was also fabricated for a comparative study and characterized as in the case of the P3HT:diarylmethanofullerene derivatives device.

\section{Supporting Information}

Experimental procedures for the preparation of derivatives 1b-k, 2.

\section{Supporting Information File 1 \\ Experimental methods \\ [http://www.beilstein-journals.org/bjoc/content/ \\ supplementary/1860-5397-5-7-S1.pdf]}

\section{Acknowledgments}

This work was supported by the Incorporated Administrative Agency New Energy and Industrial Technology Development 
Organization (NEDO) under the Japanese Ministry of Economy, Trade and Industry (METI).

\section{References}

1. Sariciftci, N. S.; Smilowitz, L.; Heeger, A. J.; Wudl, F. Science 1992, 258, 1474-1476. doi:10.1126/science.258.5087.1474

2. Yu, G.; Gao, J.; Hummelen, J. C.; Wudl, F.; Heeger, A. J. Science 1995, 270, 1789-1791. doi:10.1126/science.270.5243.1789

3. Brabec, C. J.; Sariciftci, N. S.; Hummelen, J. C. Adv. Funct. Mater. 2001, 11, 15-26. doi:10.1002/1616-3028(200102)11:1<15::AID-ADFM15>3.0.CO;2-A

4. Hoppe, H.; Sariciftci, N. S. J. Mater. Res. 2004, 19, 1924-1945. doi:10.1557/JMR.2004.0252

5. Brabec, C. J. Sol. Energy Mater. Sol. Cells 2004, 83, 273-292. doi:10.1016/j.solmat.2004.02.030

6. Günes, S.; Neugebauer, H.; Sariciftci, N. S. Chem. Rev. 2007, 107, 1324-1338. doi:10.1021/cr050149z

7. Janssen, R. A. J.; Hummelen, J. C.; Lee, K.; Pakbaz, K.; Sariciftci, N. S.; Heeger, A. J.; Wudl, F. J. Chem. Phys. 1995, 103, 788-793. doi:10.1063/1.470110

8. Camaioni, N.; Ridolfi, G.; Casalbore-Miceli, G.; Possamai, G.; Maggini, M. Adv. Mater. 2002, 14, 1735-1738.

doi:10.1002/1521-4095(20021203)14:23<1735::AID-ADMA1735>3.0.C O;2-O

9. Riedel, I.; Dyakonov, V. Phys. Status Solidi A 2004, 201, 1332-1341. doi:10.1002/pssa.200404333

10. Padinger, F.; Rittberger, R. S.; Sariciftci, N. S. Adv. Funct. Mater. 2003, 13, 85-88. doi:10.1002/adfm.200390011

11. Janssen, R. A. J.; Hummelen, J. C.; Sariciftci, N. S. MRS Bull. 2005, 30, 33-36.

12. Li, G.; Shrotriya, V.; Huang, J.; Yao, Y.; Moriarty, T.; Emery, K.; Yang, Y. Nat. Mater. 2005, 4, 864-868. doi:10.1038/nmat1500

13. Ma, W.; Yang, C.; Gong, X.; Lee, K.; Heeger, A. J. Adv. Funct. Mater. 2005, 15, 1617-1622. doi:10.1002/adfm.200500211

14. Reyes-Reyes, M.; Kim, K.; Carroll, D. L. Appl. Phys. Lett. 2005, 87, No. 083506. doi:10.1063/1.2006986

15. Kim, Y.; Cook, S.; Tuladhar, S. M.; Choulis, S. A.; Nelson, J.; Durrant, J. R.; Bradley, D. D. C.; Giles, M.; McCulloch, I.; Ha, C.-S.; Ree, M. Nat. Mater. 2006, 5, 197-203. doi:10.1038/nmat1574

16. Kim, J. Y.; Kim, S. H.; Lee, H.-H.; Lee, K.; Ma, W.; Gong, X.; Heeger, A. J. Adv. Mater. 2006, 18, 572-576. doi:10.1002/adma.200501825

17. Kim, K.; Liu, J.; Namboothiry, M. A. G.; Carroll, D. L. Appl. Phys. Lett. 2007, 90, No. 163511. doi:10.1063/1.2730756

18. Knight, B.; Martín, N.; Ohno, T.; Ortí, E.; Rovira, C.; Veciana, J.; Vidal-Gancedo, J.; Viruela, P.; Viruela, R.; Wudl, F. J. Am. Chem. Soc. 1997, 119, 9871-9882. doi:10.1021/ja962299k

19. Riedel, I.; von Hauff, E.; Parisi, J.; Martín, N.; Giacalone, F.; Dyakonov, V. Adv. Funct. Mater. 2005, 15, 1979-1987. doi:10.1002/adfm.200500097

20. Kooistra, F. B.; Knol, J.; Kastenberg, F.; Popescu, L. M.; Verhees, W. J. H.; Kroon, J. M.; Hummelen, J. C. Org. Lett. 2007, 9, 551-554. doi:10.1021/ol062666p

21. Yang, C.; Kim, J. Y.; Cho, S.; Lee, J. K.; Heeger, A. J.; Wudl, F. J. Am. Chem. Soc. 2008, 130, 6444-6450. doi:10.1021/ja710621j

22. Lenes, M.; Wetzelaer, G.-J. A. H.; Kooistra, F. B.; Veenstra, S. C.; Hummelen, J. C.; Blom, P. W. M. Adv. Mater. 2008, 20, 2116-2119. doi:10.1002/adma.200702438

23. Nakanishi, T.; Schmitt, W.; Michinobu, T.; Kurth, D. G.; Ariga, K. Chem. Commun. 2005, 5982-5984. doi:10.1039/b512320h
24. Nakanishi, T.; Miyashita, N.; Michinobu, T.; Wakayama, Y.; Tsuruoka, T.; Ariga, K.; Kurth, D. G. J. Am. Chem. Soc. 2006, 128, 6328-6329. doi:10.1021/ja061450f

25. Toru, T.; Shibata, N.; Nakamura, S.; Soga, T.; Hayashi, Y.; Singh, S. P. Soluble Fullerene Derivatives. Jpn. Pat. Appl. 07309476, November 29, 2007.

26. Hummelen, J. C.; Knight, B. W.; LePeq, F.; Wudl, F.; Yao, J.; Wilkins, C. L. J. Org. Chem. 1995, 60, 532-538. doi:10.1021/jo00108a012

27. Brabec, C. J.; Cravino, A.; Meissner, D.; Sariciftci, N. S.; Fromherz, T.; Rispens, M. T.; Sanchez, L.; Hummelen, J. C. Adv. Funct. Mater. 2001, 11, 374-380. doi:10.1002/1616-3028(200110)11:5<374::AID-ADFM374>3.0.CO;2-W

28. Shrotriya, V.; Ouyang, J.; Tseng, R. J.; Li, G.; Yang, Y. Chem. Phys. Lett. 2005, 411, 138-143. doi:10.1016/j.cplett.2005.06.027 The best performance has been reported with a 1:1 ratio of $\mathrm{P} 3 \mathrm{HT}$ and PCBM.

29. Koster, L. J. A.; Mihailetchi, V. D.; Ramaker, R.; Blom, P. W. M. Appl. Phys. Lett. 2005, 86, No. 123509. doi:10.1063/1.1889240

30. Ohkita, H.; Cook, S.; Astuti, Y.; Duffy, W.; Tierney, S.; Zhang, W.; Heeney, M.; McCulloch, I.; Nelson, J.; Bradley, D. D. C.; Durrant, J. R. J. Am. Chem. Soc. 2008, 130, 3030-3042. doi:10.1021/ja076568q

31. The HOMO and LUMO energies of the diarylmethanofullerene derivatives were estimated by the method reported. See [35]. The HOMO and LUMO values were calculated by using the following general equations: $\mathrm{E}_{\mathrm{HOMO}}=\mathrm{E}_{\mathrm{ox}}^{1}+4.4 \mathrm{eV} \mathrm{E}_{\mathrm{LUMO}}=\mathrm{E}_{\mathrm{HOMO}}-\mathrm{E}_{\mathrm{opt}}$. The energy gap between the HOMO and LUMO energies was estimated to be 2.70 by the tarc plots derived from the absorption in the UV spectrum. Thus, the LUMO energy of 1 a was estimated to be $2.95 \mathrm{eV}$. The HOMO and LUMO values of other derivatives obtained by analogy were not significantly changed from those of 1a. Unfortunately, we could not compare these LUMO levels with that of PCBM, because the oxidation potential of PCBM was not observed.

32. Li, G.; Shrotriya, V.; Yao, Y.; Yang, Y. J. Appl. Phys. 2005, 98, No. 043704. doi:10.1063/1.2008386

33. Matsumoto, F.; Moriwaki, K.; Takao, Y.; Ohno, T. Beilstein J. Org. Chem. 2008, 4, No. 33. doi:10.3762/bjoc.4.33

34. Chiu, M.-Y.; Jeng, U.-S.; Su, C.-H.; Liang, K. S.; Wei, K.-H. Adv. Mater. 2008, 20, 2573-2578. doi:10.1002/adma.200703097

35. Chen, Z.-K.; Huang, W.; Wang, L.-H.; Kang, E.-T.; Chen, B. J.; Lee, C. S.; Lee, S. T. Macromolecules 2000, 33, 9015-9025. doi: $10.1021 / \mathrm{ma} 0005670$ 


\section{License and Terms}

This is an Open Access article under the terms of the Creative Commons Attribution License

(http://creativecommons.org/licenses/by/2.0), which permits unrestricted use, distribution, and reproduction in any medium, provided the original work is properly cited.

The license is subject to the Beilstein Journal of Organic Chemistry terms and conditions:

(http://www.beilstein-journals.org/bjoc)

The definitive version of this article is the electronic one which can be found at:

doi:10.3762/bjoc. 5.7 